\title{
DNA fingerprinting of water yam (Dioscorea alata) cultivars in Brazil based on microsatellite markers
}

\author{
Marcos VBM Siqueira'; ${ }^{1}$ Gabriel Dequigiovanni' ${ }^{1}$;ike A Corazon-Guivin ${ }^{1}$; José C Feltran²; Elizabeth A Veasey ${ }^{1}$ \\ ${ }^{1}$ ESALQ, C. Postal 83, 13400-970 Piracicaba-SP; eaveasey@esalq.usp.br (author for correspondence) ${ }^{2} I A C$, Seção de Raízes e \\ Tubérculos, C. Postal 28, 13012-970 Campinas-SP
}

\begin{abstract}
This study aimed to fingerprint 36 water yam (Dioscorea alata) accessions using microsatellite markers. Ten accessions were collected in local markets from several municipalities in Brazil, eight were obtained from the 'Instituto Agronômico de Campinas' (IAC) germplasm collection and eighteen were collected directly from growers from São Paulo state. A total of nine microsatellite loci were used in the analysis. Loci revealed high polymorphism verified by elevated PIC values (0.57-0.77), and by high gene diversity and Shannon-Wiener indices (0.69 and 1.29 on average, respectively). The accessions were classified into two groups based on clustering analysis. One group contained mostly accessions from the IAC collection, including a commercial cultivar acquired in a market in the city of Cuiabá, Mato Grosso state. The second group was composed of most accessions, including those collected directly from growers and markets in São Paulo, a few accessions from the IAC collection, and an accession from Puerto Rico, named 'Florida', which is the most cultivated in Brazil. Several duplicates were identified in this study, including accessions obtained from two farmers in Mogi Guaçu and Mogi Mirim, São Paulo state. However, some of these accessions were allocated in different sub-groups, within this second group. Results suggested the hypothesis of different origins for accessions currently cultivated in Brazil. Similar accessions obtained from different municipalities revealed the commercialization of the same accessions at different locations.
\end{abstract}

Keywords: Dioscorea alata, commercial varieties, genetic diversity, germplasm collection, SSR.

\section{RESUMO}

Diversidade genética de cultivares de inhame (Dioscorea alata) no Brasil utilizando microssatélites

Este estudo teve como objetivo a análise genética de 36 acessos de inhame (Dioscorea alata) utilizando marcadores microssatélites. Dez acessos foram coletados em mercados locais de vários municípios no Brasil, oito foram obtidos no banco de germoplasma do Instituto Agronômico de Campinas (IAC), e dezoito foram coletados diretamente com os agricultores no estado de São Paulo. Um total de nove locos de microssatélites foram utilizados para amplificação. Alto polimorfismo foi encontrado entre os locos, verificado pelos valores de PIC elevados $(0,57-0,77)$ e altos índices de heterogosidade esperada e Shannon-Wiener (0,69 e 1,29 em média, respectivamente). Os acessos foram classificados em dois grupos pela análise de agrupamento. O primeiro grupo consiste principalmente de acessos obtidos da coleção do IAC, incluindo um acesso comercial obtido num mercado na cidade de Cuiabá, estado de Mato Grosso. O segundo grupo classificou os acessos coletados diretamente dos agricultores, incluindo um importante acesso proveniente de Porto Rico, denominado 'Florida', a cultivar mais plantada no Brasil. Este grupo incluiu também os acessos obtidos em mercados de vários municípios do estado de São Paulo, além de outros acessos da coleção do IAC. Várias duplicatas foram identificadas neste estudo, incluindo acessos obtidos junto aos dois agricultores de Mogi Guaçu e Mogi Mirim, em São Paulo. Entretanto, parte desses acessos foi alocada em diferentes sub-grupos, dentro do segundo grupo. Os resultados sugerem a hipótese de diferentes origens para os acessos atualmente comercializados e cultivados no Brasil. Acessos similares obtidos de diferentes municípios mostrou a comercialização dos mesmos em locais diferentes.

Palavras-chave: Dioscorea alata, banco de germoplasma, diversidade genética, SSR, variedades comerciais.

(Recebido para publicação em 30 de janeiro de 2012; aceito em 16 de outubro de 2012)

(Received on January 30, 2012; accepted on October 16, 2012)

$\mathrm{W}$ ater yam (Dioscorea alata), also known as "greater yam", was never found in the wild and its hybridization with other Dioscorea species is unknown, although two Asian species (D. hamiltonii and D. persimilis) could be part of its origins (Burkill, 1960). Water yam is believed to be a true cultigen derived from wild forms through human selection, although there is no concrete evidence to support this claim (Hahn, 1995). Tubers from this species are known for their high nutritional content, with crude protein content of $7.4 \%$, starch content of 75 $84 \%$, and vitamin $\mathrm{C}$ content ranging from 13.0 to $24.7 \mathrm{mg} / 100 \mathrm{~g}$. Due to high starch content of the tubers, $D$. alata provides a good source of dietary carbohydrates in tropical and subtropical regions (Osagie, 1992).

World annual production of yam, in 2010, was estimated to be 48.3 million tons (FAOSTAT, 2012). About $94 \%$ of this production was from Western and Middle Africa, with Nigeria being the world largest producer, the remaining was produced mainly in Central and South America, Oceania and Asia (FAOSTAT, 2012). Brazilian yam production, including $D$. alata and $D$. cayenensis/D. rotundata species, was estimated to be 232,100 tons in 2010 in a cultivated area of 25,300 ha (FAOSTAT, 2012), concentrated in the Northeastern and Southeastern regions, grown mainly 
by small-scale farmers and in reduced planting areas, in the states of Paraíba, Pernambuco, Bahia, Alagoas, Minas Gerais, São Paulo and Espírito Santo, accounting for roughly $55 \%$ of total national yield (Mesquita, 2001). Smallscale farmers produce $D$. alata in most Brazilian states (Veasey et al., 2010).

Dioscorea alata is a polyploid, with several ploidy levels, revealing a predominance of tetraploidy (Arnau et al., 2009; Obidiegwu et al., 2009a). Effective breeding programs, genetic diversity analyses and elucidation of the phylogeny and the species origin are urgently necessary (Lebot, 2009).

Despite a growing interest in water yam, published data on molecular characterization and genetic diversity of this crop are scanty (Siqueira, 2011). Few studies on genetic diversity of water yam have been reported using isozymes (Lebot et al., 1998; Bressan et al., 2011), RAPDs (Random amplified polymorphic DNA) (Asemota et al., 1996; Mignouna et al., 2002; Zannou et al., 2009), AFLPs (Amplified fragments length polymorphism) (Malapa et al., 2005; Egesi et al., 2006; Tamiru et al., 2007) and Expressed Sequence Tags (Narina et al., 2011), with each method differing in terms of principle, application, type and amount of polymorphism detected and time requirements (Agarwal et al., 2008). Microsatellites or SSR (Simple sequence repeats) markers are, in general, more abundant in most genomes, possessing highly informative content. Microsatellite primers have been developed for a few Dioscorea species (Mizuki et al., 2005; Hochu et al., 2006), including D. alata (Tostain et al., 2006; Siqueira et al., 2011), and have been used on segregation studies, and genetic characterization of Dioscorea species (Mignouna et al., 2003; Scarcelli et al., 2005; Bousalem et al., 2006; Tostain et al., 2007; Arnau et al., 2009; Obidiegwu et al., 2009b,c).

Little is known about the genetic variability of Brazilian accessions. Knowledge of the genetic variation within and among accessions is necessary for efficient breeding and management programs. This study aimed to assess the genetic diversity of $36 \mathrm{D}$. alata commercial cultivars obtained from markets in various municipalities in Brazil, and accessions introduced from Puerto Rico and the Democratic Republic of Congo, using SSR markers, and to infer about possible origins of accessions commercialized in Brazil.

\section{MATERIAL AND METHODS}

Thirty six accessions from the germplasm collections of the 'Instituto Agronômico de Campinas' (IAC) and from the Escola Superior de Agricultura "Luiz de Queiroz", University of São Paulo (ESALQ/USP), Piracicaba, São Paulo state were studied. Ten accessions were collected from markets in distinct municipalities in Brazil; eight were obtained from the IAC collection, with part being introduced from Puerto Rico and the Democratic Republic of Congo, and 18 were collected directly in the field from farmers. From these 18 accessions, eight tubers were obtained from a farmer field in Mogi Guaçu (DGC 309.1 - 309.8), and ten tubers from a farmer field in Mogi Mirim (DGC 311.1-311.10), representing possible clones (Table 1). IAC accessions were identified as SRT, followed by a number, and the ESALQ/USP accessions, as DGC followed by a number. Tubers from each accession were planted in pots in a greenhouse and further, the plantlets were transferred to the field.

Recently expanded young leaves were collected and dried in an oven at $45^{\circ} \mathrm{C}$ for $48 \mathrm{~h}$. A macerated sample was submitted to a CTAB (Cetyl Trimethyl Ammonium Bromide) extraction buffer (3\% CTAB; $1.2 \mathrm{M} \mathrm{NaCl} ; 0.1 \mathrm{M}$ TRIS $\mathrm{HCl}, \mathrm{pH} 8.0$; 30 mM EDTA, pH 8.0; $1 \% \beta$-Mercapthoethanol added just before use), following the procedure described in Sharma et al. (2008), with modifications. During each wash solution with ethanol $70 \%$ we used two extra centrifugations (5900 $\mathrm{g}$ for $300 \mathrm{~s})$, and an extended time (2 h) with RNAse incubation. DNA quality was visually assessed on 1\% agarose gels, stained with Blue Green Loading Dye (LGC Biotechnology, Brazil) following electrophoresis at $2.7 \mathrm{~V} / \mathrm{cm}$. DNA concentration was determined with known concentrations of undigested $\lambda$
DNA (Invitrogen, CA, USA) varying from 5 to $100 \mathrm{ng} / \mathrm{uL}$. The gel was visualized by UV and photo documented (Canon Utilities Remote Capture DC).

Nine microsatellite loci based on Tostain et al. (2006) and Siqueira et al. (2011) were used (Table 2). The polymerase chain reactions (PCR) were conducted in a final volume of $16 \mu \mathrm{L}$, consisting of $1 \mathrm{U}$ of Taq DNA polymerase (LGC, Brazil); 1X Amplification Buffer $\left(\mathrm{Mg}^{+}\right.$free $) ; 1.5 \mathrm{mM}$ of $\mathrm{MgCl}_{2} ; 0.3 \mu \mathrm{M}$ of each primer; $0.2 \mathrm{mM}$ of each dNTPs and $20 \mathrm{ng}$ of DNA template. Reactions were conducted in the thermocycler Bioer Lifepro (Brazil) model, under the following amplification conditions: initial denaturing at $94^{\circ} \mathrm{C}$ for $5 \mathrm{~min}$, followed by 35 cycles of denaturing at $94^{\circ} \mathrm{C}$ for $30 \mathrm{~s}, 1 \mathrm{~min}$ at the defined annealing temperature for each primer (Table 2), and $1 \mathrm{~min}$ at $72^{\circ} \mathrm{C}$, with a final extension at $72^{\circ} \mathrm{C}$ for $8 \mathrm{~min}$ (Tostain et al., 2006). Amplification products were submitted to electrophoresis in 6\% denaturing polyacrylamide gels under an initial voltage of $60 \mathrm{~V}$ for $30 \mathrm{~min}$ and $120 \mathrm{~V}$ for $3 \mathrm{~h}$. Gels were stained using a silver staining procedure (Creste et al., 2001) and photo-documented with a digital camera.

The number of alleles (bands) per loci was recorded and the Polymorphism Information Content (PIC) was calculated according to Botstein et al. (1980). The expected heterozygosity $\left(H_{E}\right)$ was also determined. PIC and $H_{E}$ were calculated according to Botstein et al. (1980). To estimate the ShannonWiener Diversity Index for each locus we used POPGENE v. 1.32 (Yeh et al., 1997).

A similarity matrix was obtained for the 36 yam accessions using binary data and the Jaccard similarity coefficient method. With this coefficient and the UPGMA (Unweighted Pair Group Method with an Arithmetic Mean) method (Sneath \& Sokal, 1973), a cluster analysis was conducted using the NTSYS-pc software (Rohlf, 1992). The precision of the generated groupings was estimated from sampling simulations, considering 10,000 bootstraps, using BOOD, version 2.0 software (Coelho, 2001). Analysis on principal coordinates and the scatter graph using the two 
first principal coordinates was also accomplished with the NTSYS-pc software (Rohlf, 1992).

\section{RESULTS AND DISCUSSION}

Despite the fact that 12 microsatellite markers were used, only nine showed polymorphism across the analyzed accessions, producing well-defined and reproducible fragments. A total of 45 alleles (fragments) was recorded with an average of 5 alleles per loci (Table 2 ). The highest number of alleles (7) was recorded for loci $A 7$, and the lowest number (4) was found for loci $A 4, F 1$,
$H 12$ and $9 C$.

Gene diversity or the expected heterozygosity $\left(H_{E}\right)$ was high in this study, 0.69 on average, varying from 0.52 (locus $B 5$ ) to 0.79 (locus $A 7$ ), as well as the Shannon-Wiener diversity index, 1.29 on average, varying from 0.82 (locus $B 5)$ to 1.65 (locus $A 7$ ). This

Table 1. List of 36 Dioscorea alata accessions used in this study, including their origin and common names (lista dos 36 acessos de Dioscorea alata usados neste estudo, incluindo suas origens e nomes comuns). Piracicaba, ESALQ, 2011.

\begin{tabular}{|c|c|c|c|c|c|}
\hline $\mathbf{N}^{0}$ & Germplasm $\mathbf{N}^{01}$ & Municipalities/state/country & Introduction year & Origin & Common name \\
\hline 1 & SRT 24.0 & Sorocaba - SP - Brazil & 1947 & IAC & Sorocaba \\
\hline 2 & SRT 71.0 & Congo Belga & 1949 & IAC & Bira \\
\hline 3 & SRT 80.0 & Minas Gerais - Brazil & 1949 & IAC & Branco Viçosa \\
\hline 4 & SRT 3.0 & Campinas - SP - Brazil & 1936 & IAC & Mimoso \\
\hline 5 & SRT 84.0 & Campinas - SP - Brazil & 1951 & IAC & Cova Campinas \\
\hline 6 & SRT 112.0 & Mato Grosso do Sul - Brazil & 2000 & IAC & Cará do Mato \\
\hline 7 & SRT 29.0 & Puerto Rico & 1947 & IAC & Florida \\
\hline 8 & SRT 89.0 & Araraquara - SP - Brazil & 1959 & IAC & Araraquara I \\
\hline 9 & DGC 45 & Campinas - SP - Brazil & 2002 & Market & --- \\
\hline 10 & DGC 40 & Piracicaba - SP - Brazil & 2002 & Market & --- \\
\hline 11 & DGC 43 & Matão - SP - Brazil & 2002 & Market & --- \\
\hline 12 & DGC 46 & Piracicaba - SP - Brazil & 2002 & Market & --- \\
\hline 13 & DGC 97.0 & Cuiabá - MT - Brazil & 2006 & Market & --- \\
\hline 14 & DGC 107.0 & Botucatu - SP - Brazil & 2006 & Market & --- \\
\hline 15 & DGC 36 & CEASA - SP - Brazil & 2002 & Market & --- \\
\hline 16 & DGC 132.0 & Fernandópolis - SP - Brazil & 2007 & Market & --- \\
\hline 17 & DGC 123.0 & Mogi-Guaçu - SP - Brazil & 2006 & Market & --- \\
\hline 18 & DGC 127.0 & Santa Mercedes - SP - Brazil & 2007 & Market & --- \\
\hline 19.1 & DGC 309.1 & Mogi Guaçú - SP - Brazil & 2009 & Farmer & Florida \\
\hline 19.2 & DGC 309.2 & Mogi Guaçú - SP & 2009 & Farmer & Florida \\
\hline 19.3 & DGC 309.3 & Mogi Guaçú - SP & 2009 & Farmer & Florida \\
\hline 19.4 & DGC 309.4 & Mogi Guaçú - SP & 2009 & Farmer & Florida \\
\hline 19.5 & DGC 309.5 & Mogi Guaçú - SP & 2009 & Farmer & Florida \\
\hline 19.6 & DGC 309.6 & Mogi Guaçú - SP & 2009 & Farmer & Florida \\
\hline 19.7 & DGC 309.7 & Mogi Guaçú - SP & 2009 & Farmer & Florida \\
\hline 19.8 & DGC 309.8 & Mogi Guaçú - SP & 2009 & Farmer & Florida \\
\hline 20.1 & DGC 311.1 & Mogi Mirim - SP - Brazil & 2009 & Farmer & cará \\
\hline 20.2 & DGC 311.2 & Mogi Mirim - SP - Brazil & 2009 & Farmer & cará \\
\hline 20.3 & DGC 311.3 & Mogi Mirim - SP - Brazil & 2009 & Farmer & cará \\
\hline 20.4 & DGC 311.4 & Mogi Mirim - SP - Brazil & 2009 & Farmer & cará \\
\hline 20.5 & DGC 311.5 & Mogi Mirim - SP - Brazil & 2009 & Farmer & cará \\
\hline 20.6 & DGC 311.6 & Mogi Mirim - SP - Brazil & 2009 & Farmer & cará \\
\hline 20.7 & DGC 311.7 & Mogi Mirim - SP - Brazil & 2009 & Farmer & cará \\
\hline 20.8 & DGC 311.8 & Mogi Mirim - SP - Brazil & 2009 & Farmer & cará \\
\hline 20.9 & DGC 311.9 & Mogi Mirim - SP - Brazil & 2009 & Farmer & cará \\
\hline 20.10 & DGC 311.10 & Mogi Mirim - SP - Brazil & 2009 & Farmer & cará \\
\hline
\end{tabular}

${ }^{1}$ SRT: germplasm from the Agronomic Institute (IAC); DGC: germplasm from USP-ESALQ; unknown variety name (SRT: germoplasma do IAC; DGC: germoplasma da USP-ESALQ; nome da variedade desconhecido). 
Table 2. Polymorphism detected based on SSR primers, including annealing temperature (Temp), fragment size, allele (band) number (A), expected heterozigosity $\left(H_{E}\right)$, ShannonWiener diversity index and polymorphism information content (PIC) when assessing 36 Dioscorea alata accessions (polimorfismo detectado, baseado em primers SSR, incluindo temperatura de anelamento (Temp), tamanho do fragmento, número (A) de alelos (bandas), heterozigosidade esperada $\left(H_{E}\right)$, índice de diversidade de Shannon-Wiener e informação do conteúdo de polimorfismo (PIC) na avaliação de 36 acessos de Dioscorea alata). Piracicaba, ESALQ, 2011.

\begin{tabular}{lcccccc}
\hline Primers & $\begin{array}{c}\text { Temp } \\
\left({ }^{\circ} \mathbf{C}\right)\end{array}$ & $\begin{array}{c}\text { Fragment size } \\
(\mathbf{b p})\end{array}$ & $\boldsymbol{A}$ & $\boldsymbol{H}_{\boldsymbol{E}}$ & Shannon-Wiener & PIC \\
\hline $\mathrm{A} 4^{1}$ & 53 & $140-180$ & 4 & 0.69 & 1.25 & 0.65 \\
$\mathrm{~B} 5^{1}$ & 60 & $100-145$ & 5 & 0.52 & 0.82 & 0.61 \\
$\mathrm{C} 5^{1}$ & 58 & $210-270$ & 5 & 0.78 & 1.56 & 0.77 \\
$\mathrm{E}^{1} 1^{1}$ & 55 & $165-190$ & 6 & 0.78 & 1.59 & 0.74 \\
$\mathrm{~F}^{1}$ & 58 & $145-205$ & 4 & 0.71 & 1.31 & 0.66 \\
$\mathrm{~A} 7^{*}$ & 52 & $215-250$ & 7 & 0.79 & 1.65 & 0.75 \\
$\mathrm{H} 12^{1}$ & 53 & $310-325$ & 4 & 0.68 & 1.18 & 0.60 \\
$\mathrm{E}^{1} 0^{1}$ & 58 & $190-250$ & 6 & 0.68 & 1.18 & 0.62 \\
$9 \mathrm{C}^{2}$ & 58 & $140-180$ & 4 & 0.62 & 1.08 & 0.57 \\
\hline Mean & & & 5 & 0.69 & 1.29 & 0.66 \\
\hline
\end{tabular}

${ }^{1}$ Siqueira et al. (2011) ${ }^{2}$ Tostain et al. (2006); ${ }^{*}$ Unpublished primer (F: GCCCCACCTTAATTTCAT; R: GGAATGAGATGGGACGAGAA).

high diversity might be due to the fact that this is a vegetatively propagated crop, which usually maintains high heterozygosity levels (Hancock, 2004). According to Obidiegwu et al. (2009b), yams are dioecious plants and spontaneous hybridization must have contributed to the ancestry of some of the accessions, although the selection of somatic mutants might have been the main source of variability used by farmers in their plant improvement practices.

PIC values ranged from 0.57 to 0.77 , with an average of 0.66 . The highest value was obtained for locus $C 5$ and the lowest, for locus 9C. PIC refers to the value of a marker for detecting polymorphism within a population, depending on the number of detectable alleles and the distribution of their frequency, and has been proven to be a general measure of how informative a marker is (Guo \& Elston, 1999). PIC values demonstrated that the SSRs used in the current study presented, on average, high level of information. Similar PIC values were reported by Obidiegwu et al. (2009b) when assessing $D$. alata accessions with 13 loci (PIC $=0.65$ on average, varying from 0.30 to 0.83 ) and by Obidiegwu et al. (2009c) when assessing $D$. cayenensis/D. rotundata accessions with 15 SSR loci $(\mathrm{PIC}=0.65$, on average, varying from 0.37 to 0.80 ).

The 36 accessions were divided in two groups by the cluster analysis, based on the bootstrap analysis (Figure 1). The first group (group I) mostly contained accessions from the IAC germplasm collection, such as SRT 24.0 (Sorocaba, originated from Sorocaba, São Paulo), SRT 80.0 (Branco Viçosa, originated from Minas Gerais), SRT 71.0 (Bira, originated from The Democratic Republic of the Congo), SRT 112.0 (Cará do Mato, originated from Mato Grosso do Sul), and an accession obtained in a market at Cuiabá, Mato Grosso.

The second group (group II) was composed by most of the accessions, including commercial cultivars from two growers in São Paulo (in the municipalities of Mogi Guaçu and Mogi Mirim). This group contained a mix of accessions obtained from markets in São Paulo municipalities, such as Piracicaba, Campinas, Matão, Botucatu, Araraquara, Fernandópolis and Santa Mercedes, and a few accessions from the
IAC collection. SRT 29.0 accession $\left(\mathrm{n}^{\mathrm{o}}\right.$ 7) originated from Puerto Rico, called Florida variety, was also included in group II. This variety was introduced in Brazil in 1947, and we do not know whether both 'Florida' and 'Florido' are the same variety, although both of them originated in Puerto Rico.

According to Martin et al. (1975), apud Lebot (2009), an international D. alata germplasm collection was maintained by the US Department of Agriculture in Mayaguez, Puerto Rico, in the 1970s, and more than 300 accessions collected throughout the tropics were evaluated regarding 100 traits in the field, at harvest and in the laboratory. This work resulted in the selection of five elite varieties, one of them being 'Florido'. The others were 'Forastero', 'Veeven', 'Gemelos' and 'Leone Globe'. 'Florido' was introduced into Ivory Coast from Puerto Rico in the early 1950s, and 'Florido' was widely adopted by farmers, spreading to other countries in West Africa. Reasons for Florido's popularity include its flexibility of planting time, good storage ability and postharvest, and tolerance to the internal brown spot disease (causal agent), which usually affects other $D$. alata varieties in Ivory Coast (Lebot, 2009). In the 1940's and 1950's many horticulture crops were launched by 'Instituto Agronômico de Campinas' (IAC). Clones of D. alata with resistance to fungal diseases, particularly to leaf blight (Curvularia maculans), which decimated the plantings in São Paulo, were made available to farmers. In this context, the clone 'Florida' (SRT 29.0) appealed to farmers for disease resistance and high productivity, which favored the expansion of its cultivation in São Paulo and in Brazil (Feltran, J.C., personal communication).

Historical records from IAC showed that two varieties, 'Florida' and 'Sorocaba', were released, due to their resistance to anthracnose and nematodes, and also commercial value. There are other $D$. alata cultivars commercialized in Brazil, known as 'São Tomé', 'Mandioca', 'Nambu', 'Roxo de Ilheus', 'Caipira', 'Purple de Ceilão', 'Paraná', and 'Nigéria' (Santos, 1996). 'Florida' is currently 


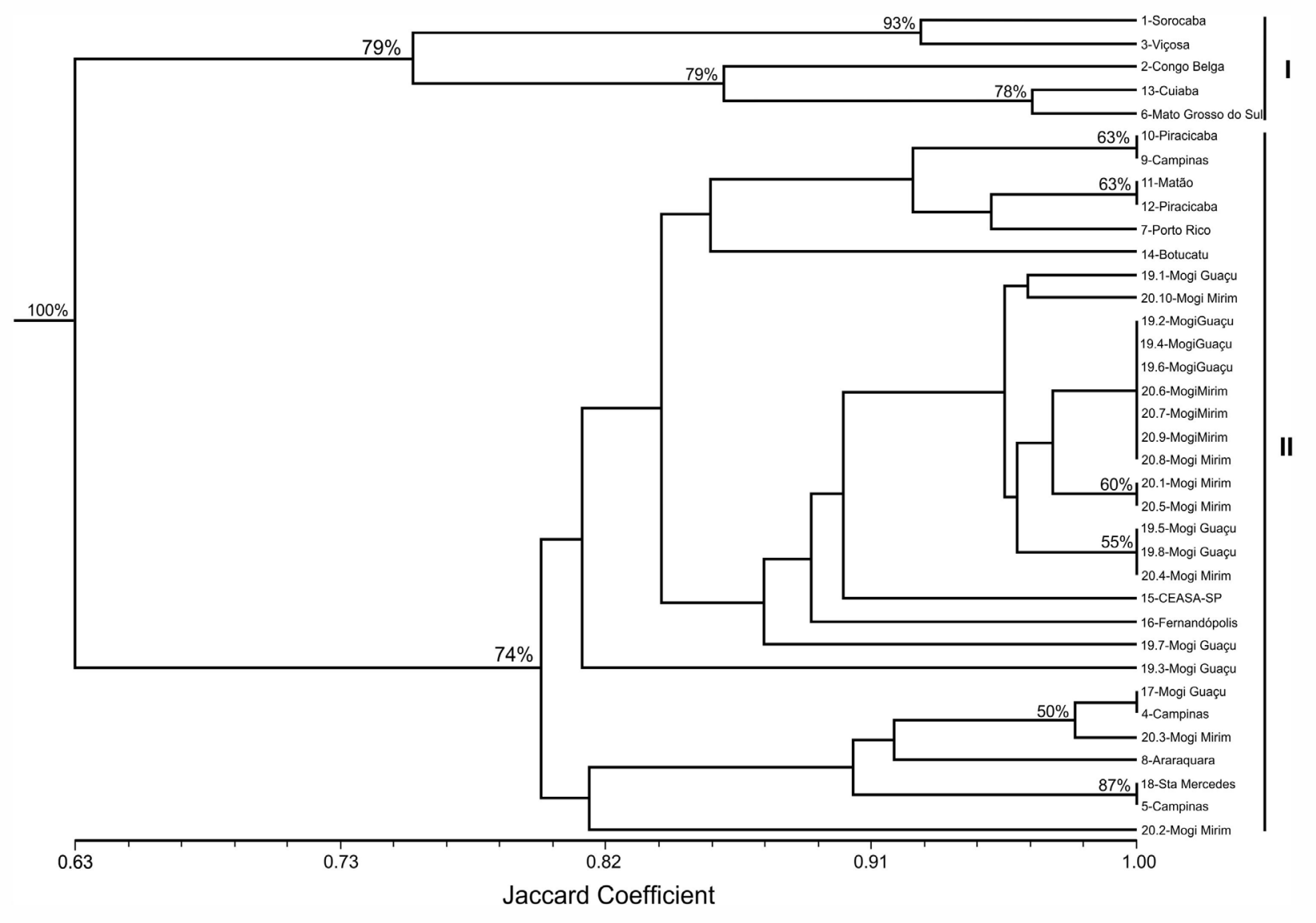

Figure 1. Dendrogram obtained by UPGMA method using Jaccard similarity coefficient and the bootstrap method (\%), for 36 Dioscorea alata accessions (dendrograma obtido pelo método UPGMA usando o coeficiente de similaridade de Jaccard e o método bootstrap (\%)). Piracicaba, ESALQ, 2011.

the most commercially accepted variety in São Paulo (Monteiro \& Peressin, 2002). It has an adequate commercial value in Brazil, showing uniform tubers with smooth skin, although culinary characteristics are of lower quality when compared to 'Mimoso' (SRT 3.0; $\mathrm{n}^{\circ} 4$ ), which is no longer cultivated in the country (Monteiro \& Peressin, 2002), because of its high susceptibility to anthracnose (causal agent Colletotrichum gloeosporioides). Therefore, it was no surprise to find in this study that most of the commercial accessions (clustered in group II), collected from several markets in Brazil, showed higher similarity $(>80 \%)$ to the most popular 'Florida' variety.

The accession acquired in a market at Cuiabá, classified in group I of the dendrogram $\left(n^{\circ} 13\right.$, Figure 1$)$ bears great similarity to the IAC accession 'Cará do mato' (SRT 112.0; $\mathrm{n}^{\circ}$ 6), originated from Mato Grosso do Sul. Therefore, the commercial variety obtained at a market in Cuiabá might have been originated from this IAC accession. Or it can also be inferred that both of them were originated from 'Sorocaba', which was also released in the country, according to the IAC records mentioned above.

A previous hypothesis was that the tubers collected from farms in Mogi Mirim and Mogi Guaçu would be genetically identical or clones. Agreeing with this hypothesis, several duplicates were found in this study, and the main duplicates belonged to the Mogi Mirim and Mogi Guaçu accessions, within group II. These duplicates were genetically similar (Figure 1) to $\mathrm{n}^{\circ} 15$ (CEASA) variety, which is a variety acquired at CEASA (Center for Distribution of Agricultural Products), in the city of São Paulo. Usually, water yam growers buy their seed-tubers directly from CEASA, and not from the nearest markets in their own municipalities. Since CEASA has a wider transportation system, it is cheaper for markets to buy yams directly from them rather than from the nearby small-scale farmer.

Another finding was that not all tubers from these two farms were genetically identical, since some of these tubers gave origin to plants that were clustered in distinct sub-groups, but all within group II. One of them $\left(\mathrm{n}^{\circ} 20.3\right.$ in the dendrogram, Figure 1) was shown to be highly similar to the 'Mimoso' (SRT 3.0, $\mathrm{n}^{\circ} 4$ in the dendrogram), which was also shown to be a duplicate to an accession obtained from another farm in Mogi Guaçu ( ${ }^{\circ}$ 17). These three accessions were genetically closer to SRT 89.0, from Araraquara ('Araraquara I'), from the IAC collection. Another accession from the IAC collection was 
included in this sub-group, called variety ‘cova Campinas' (SRT 84.0, n 5), which was shown to be a duplicate of an accession collected in Santa Mercedes, São Paulo state.

Other duplicates were identified in the dendrogram, such as the commercial variety $n^{\circ} 10$, from a market in Piracicaba and $\mathrm{n}^{\circ} 9$ from a market in Campinas. Other duplicates included commercial varieties collected in markets of Matão $\left(n^{\circ} 11\right)$ and Piracicaba $\left(n^{\circ} 12\right)$, also municipalities in São Paulo $170 \mathrm{~km}$ apart. These results show that genetically identical varieties are commercialized in different locations, at least in the state of São Paulo.

The cluster analysis conducted by Malapa et al. (2005) using AFLPs revealed the existence of three major groups of genotypes within D. alata, each assembling accessions from distant geographical origins and distinct ploidy levels. However, Lebot et al. (1998), examining the genetic relationship among 269 cultivars of $D$. alata from the South Pacific, Asia, Africa and the Caribbean with isozymes, concluded that the most widespread $D$. alata cultivars exhibited a narrow genetic base. Higher polymorphism was detected by Zannou et al. (2009) using RAPD markers, when assessing both $D$. alata and $D$. cayenensis/D. rotundata accessions from the Guinea-Sudan zone of Benin. These polymorphic DNA fragments were used to build dendrograms, clustering all accessions into 18 groups: 12 for $D$. cayenensis/D. rotundata and six for D. alata. Obidiegwu et al. (2009b), evaluating 89 accessions from nine African countries with SSR found non-distinction between country cultivars of D. alata. According to these authors, these accessions must have been distributed over great distances as clones during centuries of human migration and it is possible that some of them share common origins. The authors also stated that the majority of accessions within clusters are most likely clones of a common source. This observation agrees with our data, since most of the accessions in group II are probably clones originated from a common source. We also believe, as pointed by Obidiegwu et al. (2009b), that Brazilian farmers had an important role in the selection of somatic mutants, which probably had a great contribution to the range of diversity within these accessions.

The scatter graph resulting from the principal coordinate analysis (data not show), in which the first two principal coordinates accounted for $87.4 \%$ of total variance, agreed with the clustering of genotypes presented in the dendrogram, allowing the visualization of the two groups previously mentioned. In a three dimensional plot with $89 D$. alata accessions from nine countries, Obidiewgu et al. (2009b) identified eight groups although the authors underlined that there was no relationship between relatedness of the accessions and their geographical area of collection.

Here, the use of microsatellite markers allowed the identification of considerable genetic variability among 36 D. alata accessions. Results provided more information concerning the genetic origin of $D$. alata commercial varieties currently cultivated in Brazil, and about their market distribution. According to Dansi et al. (2000), assessment on genetic diversity within Dioscorea spp. will serve as an instrument to identify cultivar misclassification, help to understand the relationships between cultivars, and assist in identifying putative duplicates towards the establishment of an accurate core collection. However, additional studies, involving a higher number of accessions and microsatellite markers, should be accomplished to better understand how the germplasm of this species is structured and organized, as well as the origins of commercial varieties cultivated in Brazil. These SSR loci represent an important molecular tool to build genetic profiles of yam cultivars, showing potential to be used in plant breeding programs and in ex situ yam conservation programs as well.

\section{ACKNOWLEDGEMENTS}

The authors thank FAPESP for the financial support and grants provided to this research. We also thank the agriculturists for the contributions in the field collecting and the journal reviewers for their excellent suggestions.

\section{REFERENCES}

AGARWAL M; SHRIVASTAVA N; PADH H. 2008. Advances in molecular marker techniques and their applications in plant sciences. Plant Cell Reports 27: 617-631.

ARNAU G; NEMORIN A; MALEDON E; ABRAHAM K. 2009. Revision of ploidy status of Dioscorea alata L. (Dioscoreaceae) by cytogenetic and microsatellite segregation analysis. Theoretical and Applied Genetics 118: 1239-1249.

ASEMOTA HN; RAMSER J; LOPÉZ-PERALTA C; WEISING K; KAHL G. 1996. Genetic variation and cultivar identification of Jamaican yam germplasm by random amplified polymorphic DNA analysis. Euphytica 92: 341-351.

BOTSTEIN D; WHITE R; SKOLNICK M; DAVIS R. 1980. Construction of a genetic linkage map in man using restriction fragment length polymorphisms. The American Journal of Human Genetics 32: 314-31.

BOUSALEM M; ARNAU G; HOCHU I; ARNOLIN R; VIADER V; SANTONI S; DAVID J. 2006. Microsatellite segregation analysis and cytogenetic evidence for tetrasomic inheritance in the American yam Dioscorea trifida and a new basic chromosome number in the Dioscoreae. Theoretical and Applied Genetics 113: 439-451.

BRESSAN EA; BRINER NETO T; ZUCCHI MI; RABELLO RJ; VEASEY EA. 2011. Morphological variation and isozyme diversity in Dioscorea alata L. landraces from Vale do Ribeira, Brazil. Scientia Agrícola 68: 494-502.

BURKILL IH. 1960. Organography and evolution of Dioscoreaceae, the family of yams. Journal of the Linnean Society 56: 319-412.

COELHO ASG. 2001. BOOD: avaliação de dendrogramas baseados em estimativas de distâncias/similaridades genéticas através do procedimento de bootstrap, v. 2.0. Goiânia: Departamento de Biologia Geral, Instituto de Ciências Biológicas, Universidade Federal de Goiás.

CRESTE S; TULMANN-NETO A; FIGUEIRA A. 2001. Detection of single sequence repeat polymorphism in denaturing polyacrylamide sequencing gels by silver staining. Plant Molecular and Biology Reporter 19: 299-306.

DANSIA; MIGNOUNAHD;ZOUNDJIHÉKPON J; SANGAREA; AHOUSSOU N; ASIEDU R. 2000. Identification of some Benin Republic's Guinea yam (Dioscorea cayenensis/rotundata complex) cultivars using Randomly Amplified Polymorphic DNA. Genetic Resource and Crop Evolution 47: 619-625.

EGESI CN; ASIEDU R; UDE G; OGUNYEMI S; EGUNJOBI JK. 2006. AFLP marker diversity in water yam (Dioscorea alata L.). Plant Genetic Resource 4: 181-187.

FAOSTAT - Food and Agriculture Organization of the United Nations. 2012. Production: crops. Available at: http://faostat.fao.org/ 
site/567/default.aspx\#ancor. Accessed at: 27 September 2012.

GUO X; ELSTON RC. 1999. Linkage informative content of polymorphic genetic markers. Human Heredity 49: 112-118.

HAHN SK. 1995. Yams, Dioscorea spp. (Dioscoreaceae). In: SMARTT J; SIMMONDS NW (eds). Evolution of crops plants. London: Longman Group Limited. p. 112-120.

HANCOCK JF. 2004. Plant evolution and the origin of crop species. Wallingford: CABI Publishing. 324p.

HOCHU I; SANTONI S; BOUSALEM M. 2006. Isolation, characterization and cross-species amplification of microsatellite DNA loci in the tropical American yam Dioscorea trifida. Molecular Ecology Notes 6: 137-140.

LEBOT V. 2009. Tropical root and tuber crops: cassava, sweet potato, yams and aroids. Crop production science in horticulture series: 17, Wallingford: CABI Press. 413 p.

LEBOT V; TRILLES B; NOYER J; MODESTO J. 1998. Genetic relationships between Dioscorea alata L. cultivars. Genetic Resource and Crop Evolution 45: 499-509.

MALAPA R; ARNAU G; NOYER J; LEBOT V. 2005. Genetic diversity of the greater yam (Dioscorea alata L.) and relatedness to D. nummularia Lam. and D. transversa Br. as revealed with AFLP markers. Genetic Resource and Crop Evolution 52: 919-929.

MESQUITA AS. 2001. Inhame na Bahia: a produção no caminho da competitividade. Bahia Agricola 4: 39-48.

MIGNOUNA HD; ABANG MM; ONOSANYA A; ASIEDU R. 2002. Identification and application of RAPD markers for anthracnose resistance in water yam (Dioscorea alata). Annals of Applied Biology 141: 61-66.

MIGNOUNA HD; ABANG MM; FAGBEMI SA. 2003. A comparative assessment of molecular marker assays (AFLP, RAPD and SSR) for white yam (Dioscorea rotundata) germplasm characterization. Annals of Applied Biology 142: 269-276.

MIZUKI I; TANI N; ISHIDA K; TSUMURA Y. 2005. Development and characterization of microsatellite markers in a clonal plant, Dioscorea japonica Thunb. Molecular Ecology Notes 5: 721-723.
MONTEIRO DA; PERESSIN VA. 2002. Cultura do inhame. In: CEREDA MP(ed). Agricultura: tuberosas amiláceas Latino Americanas. São Paulo: Fundação Cargill, p. 511-522.

NARINA SS; BUYYARAPU R; KOTTAPALLI KR; SARTIE AM; ALI MI; ROBERT A; HODEBA MJD; SAYRE BL; SCHEFFLER BE. 2011. Generation and analysis of Expressed Sequence Tags (ESTs) for marker development in yam (Dioscorea alata L.). BMC Genomics 12: 100.

OSAGIE AU. 1992. The yam tuber in storage. Postharvest Research Unit. Benin City: University of Benin. 247 p.

OBIDIEGWU JE; RODRIGUEZ E; ENEOBONG EE; LOUREIRO J; MUONEKE CO; SANTOS C; KOLESNIKOVA-ALLEN M; ASIEDU R. 2009a. Estimation of the nuclear DNA content in some representative of genus Dioscorea. Scientific Research and Essay 4: 448-452.

OBIDIEGWU JE; ASIEDU R; ENE-OBONG EE; MUONEKE CO; KOLESNIKOVA-ALLEN M. 2009b. Genetic characterization of some water yam (Dioscorea alata L.) in West Africa with simple sequence repeats. Journal of Food, Agriculture \& Environment 7: 132-136.

OBIDIEGWU JE; KOLESNIKOVA-ALLEN M; ENE-OBONG EE; MUONEKE CO; ASIEDU R. 2009c. SSR markers reveal diversity in Guinea yam (Dioscorea cayenensis/D. rotundata) core set. African Journal of Biotechnology 8: 2730-2739.

ROHLF J. 1992. NTSYS-pc: numerical taxonomy and multivariate analysis system, version 1.70 (software). New York: Stony Brook.

SANTOS ES. 1996. Aspectos básicos da cultura do inhame (Dioscorea spp.). João Pessoa: EMEPA, SEBRAE. 158 p.

SCARCELLI N; DAÏNOU O; AGBANGLA C; TOSTAIN S; PHAM JL. 2005. Segregation patterns of isozyme loci and microsatellite markers show the diploidy of African yam Dioscorea rotundata $(2 \mathrm{n}=40)$. Theoretical and Applied Genetics 111: 226-232.

SHARMA K; MISHRA AK; MISRA RS. 2008. A simple and efficient method for extraction of genomic. DNA from tropical tuber crops. African Journal of Biotechnology 7: 10181022.
SIQUEIRA MVBM. 2011. Yam: a neglected and underutilized crop in Brazil. Horticultura Brasileira 29: 16-20.

SIQUEIRA MVBM; MARCONI TG; BONATELLI ML; ZUCCHI MI; VEASEY EA. 2011. Development and characterization of microsatellite markers in water yam (Dioscorea alata). American Journal of Botany 98: 142-146.

SNEATH PHA; SOKAL RR. 1973. Numerical taxonomy: the principles and practice of numerical classification. San Francisco: Freeman. 573 p.

TAMIRU M; BECKER HC; MAASS BL. 2007. Genetic diversity in yam germplasm from Ethiopia and their relatedness to the main cultivated Dioscorea species assessed by AFLP markers. Crop Science 47: 1744-1753.

TOSTAIN S; AGBANGLA C; SCARCELLI N; MARIAC C; BERTHAUD J; PHAM J. 2007. Genetic diversity analysis of yam cultivars (Dioscorea rotundata Poir.) in Benin using simple sequence repeat (SSR) markers. Plant Genetic Resource 5: 71-81.

TOSTAIN S; SCARCELLI N; BROTTIER P; MARCHAND JL; PHAM JL; NOYER JL. 2006. Development of DNA microsatellite markers in tropical yam (Dioscorea sp.). Molecular Ecology Notes 6: 173-175.

VEASEY EA; SIQUEIRA MVBM; GOMES LR; NASCIMENTO WF; FERREIRA, AB; SILVA DM; SILVA EF; MING LC; PERONI N; SANTOS AH. 2010. Ocorrência e diversidade de espécies cultivadas do gênero Dioscorea em diversos agroecossistemas brasileiros. In: MING LC; AMOROZO MC; KFFURI CW. (org). Agrobiodiversidade no Brasil: experiências e caminhos da pesquisa. Recife: NUPEEA, 1: 45-74.

YEH FC; YANG RC; BOYLE TBJ; YE ZH; MAO JX. 1997. POPGENE, the userfriendly shareware for population genetic analysis. Edmonton: Molecular Biology and Biotechnology Centre, University of Alberta.

ZANNOUA;AGBICODOE;ZOUNDJIHÉKPON J; STRUIK PC; AHANCHÉDÉ A; KOSSOU DK; SANNI A. 2009. Genetic variability in yam cultivars from the Guinea-Sudan zone of Benin assessed by random amplified polymorphic DNA. African Journal of Biotechnology 8: 26-36. 